\title{
A CRITICAL OVERVIEW OF THE COLLECTIVE CONTRACT PAYMENTS TO UNIONIZED PUBLIC OFFICIALS
}

\author{
Harun KILIÇASLAN ${ }^{1}$
}

\begin{abstract}
The subject of the study is public officials who are members of unions that are being paid collective contract payments in accordance with the law No. 4688 in Turkey. Public officials are able to seek rights through trade unions as well as other employees in an organized manner against the employer. The purpose of the study is to investigate the collective contract payments being made to the members of the unions, which are a group of interests and pressure groups, in the framework of finance theory. Is the collective contract payment a discriminatory practice for favor of public officials' unions? . Is the collective contract payment an unfair practice for favor of public officials' unions? Could the collective bargaining bonus encourage membership in the civil servants' unions and act as an indirect financing function? In the study, these questions were searched on the basis of the theory of finance, while in the context of the critical paradigm a qualitative research method was preferred and existing statistics research has been applied. The unionization rate of the public officials' unions, which had been granted the right to pay for the collective contract payment since 2010, increased from approximately 58\% in 2010 to approximately $68 \%$ in 2018 . It is considered that collective bargaining payments can be effective by increasing the rate of unionization. The fact that the aforementioned bonus is paid only to unionized officials appears to be problematic in terms of justice as a discriminatory practice. On the other hand, collective contract payments, which provide indirect financing, constitute a separate problem area for the unions to fulfill the function of pressure group in the defense of the economic and social rights of public employees in an independent manner and for the establishment of union consciousness. Finally, it is concluded that there is no significant theoretical basis for the collective contract bonuses included in public expenditure financed by public revenues.
\end{abstract}

Keywords: Collective Contract Payments, Pressure Groups, Trade Union, Public Finance Theory, Club Goods

JEL Code: H39, J51, J58.

\section{Introduction}

Collective bargaining bonus payments made to the members of public officials' unions in Turkey in accordance with Law No. 4688 constitute the subject of this study. As other employees, public employees can claim their rights through unions in an organized manner against the employer. The purpose of the study is to investigate the collective bargaining bonus payments to the members of the unions, which stand as interest and pressure groups against the government in the position of employer, within the framework of finance theory.

Is the collective bargaining bonus a discriminatory practice for the benefit of public officials' unions? Is it an unfair practice for the benefit of public officials' unions? Would it act as an indirect financing function, encouraging membership in the public officials' unions? Answering these questions is important for the effective allocation of public resources.

\footnotetext{
1 Asst. Prof., Sakarya University, harun@sakarya.edu.tr
} 
The methodology adopted in this report stands close to the critical paradigm. In the research, descriptive and qualitative dimension becomes prominent. In the study, 'existing statistics research', one of the unresponsive research techniques², was applied. Existing statistics research is seen to be classified within document reviews (Bailey, 1994: 294-301). Existing statistics research is the most appropriate method for research on issues related to data collected by large bureaucratic organizations (Neuman, 2011: 370). Even though mostly based on positivist principles, it is also used by interpretive researchers and critical researchers (Neuman, 2011: 359).

In the study, statistics in the 'Communiqué on the Number of Union Members of Public Officials' published by the Ministry of Family, Labor and Social Services and other statistics of the same institution were used.

\section{Public Officials' Unions in Turkey}

$>$ In 1995, the right to establish union and bargain collectively was attained after a change in the Constitution.

$>$ In 1997, an article was inserted in the Public Servants Law.

$>$ In 2001, the Public Officials' Unions Law No. 4688 was issued.

$>$ In 2006, a regulation was made on the Collective Bargaining Bonus.

$>$ In 2010, the right for collective bargaining agreement was attained instead of collective bargaining.

$>$ At present, the right to strike does not exist.

The president of a union which was placed among the big unions in terms of the number of members in Turkey in 2005 mentioned in an interview that there were two major problems in front of the public employees' syndicalism (Özcan, 2005: 128). It was mentioned in the interview that one of them was that public employees were not conscious of the benefits of being organized, and the other was that governments and bureaucracy had not yet accepted public syndicalism. The second problem was stated a little more clearly that the reactions of the unions caused discomfort on the part of the authorities and bureaucracy, that taking side among syndicates could be possible and that it could be possible to ask public employees to change their unions by putting pressure on them.

Inferring from the sources of the first problem expressed here goes beyond the purpose and scope of this study. However, it is possible to say that the union consciousness of a non-union public employee who does not pay any membership fee and a public employee with union membership who pays a membership fee is not the same. Nonetheless, the unionization rate of public employees in the year of interview is over $47 \%$ as seen in Table 1 . This rate is not insignificant. Therefore, it can be considered that union consciousness does not increase at the same rate as unionization. At least it can be considered that the unionists think this way, because the complaining of unionists with the unionization at this rate cannot be explained otherwise. In 2005, public employees did not have the right to collectively bargain with strike. They do not have this right today either, yet on the other hand, the unionization rate is getting closer to $70 \%$. Measuring the increase in the union awareness of public employees from 2005 till today can be the subject of another study. However, it is clear that the payments made to the unionized public employees four times a year under the name of collective bargaining bonus and the payments sometimes redeeming the union membership fees completely or

\footnotetext{
2 Also known as non-interventionist research strategies. See: Berg et al.
} 
almost entirely will not contribute to raising the union consciousness. When the financing comes indirectly from the public, the consciousness or need for calling to account of union members will not develop either. It is also known that the interests of persons in the goods and services that they do not pay for besides the motivation of free riding also decrease. For example, in cases where there is no obligation to attend the university education offered free of charge, even though students' tendency to attend classes is usually less, they may be more eager in attending private courses for which they pay. If it is accepted that union membership is assumed as a club good and promoted by the state, then there comes out a contradiction in terms of the rationality of the groups representing different interests. The subject of governments and bureaucracy, which is expressed as the side of the second problem in the interview, is also noteworthy. It is clear that governments do not represent the same economic interests as public employees. However, it is noteworthy that such an inference has been made by a syndicalist about the bureaucracy. What is meant by bureaucracy here can be considered to be the administrative staff, which often changes with governments. In fact, it is interesting that that is expressed that sides are taken among unions and even there are forcings for union changes shows that governments do not categorically consider unions as a subject for conflict of interest. This even reminds of a co-operation. However, it is obvious that, whatever the reasons are, the reasons pushing the governments and the unions representing the different economic interests for cooperation will prevent the proper functioning of the union system. From a different standpoint, it can be seen that the state, which intervenes in the market by regulatory means as social state, sometimes intervenes in the prices of goods and services, sometimes in the shares of the factors of production. The practice of minimum wage is one of them. While governments are pressuring the private sector on the subject of worker wages, in relation with conciousness for being a social state, such as determining the minimum wage, it is a different problematic point that public employees are expected to need or need to be organized against the same governments.

In 2018, 1,673,318 public employees were members of a union and the unionization rate was $67.65 \%$ (Ministry of Family, Labor and Social Services, 2019a). Whereas, in labor unions, $1,802,155$ workers were unionized in the same year and the unionization rate was $12.76 \%$ on the basis of registered employment. Another interesting case for labor unions is that, in the statistics from January 2003 to July 2009, the number of unionized workers reached $3,232,679$ people from $2,717,326$ people and the unionization rate reached $59.88 \%$ from $57.98 \%$ on the aforementioned dates, however, that there were significant differences in the later period. Data for the years between were not obtained, however, the number of unionized workers, which was 1,001,671 in January 2013 on the basis of registered employment , became 1,859,038 as of January 2019 and the unionization rate rose to 13.26\% from 9.21\% for the same period, respectively. (Ministry of Family, Labor and Social Services, 2019b). This indicates that positive developments regarding shadow employment could have been taken place between 2009-201 


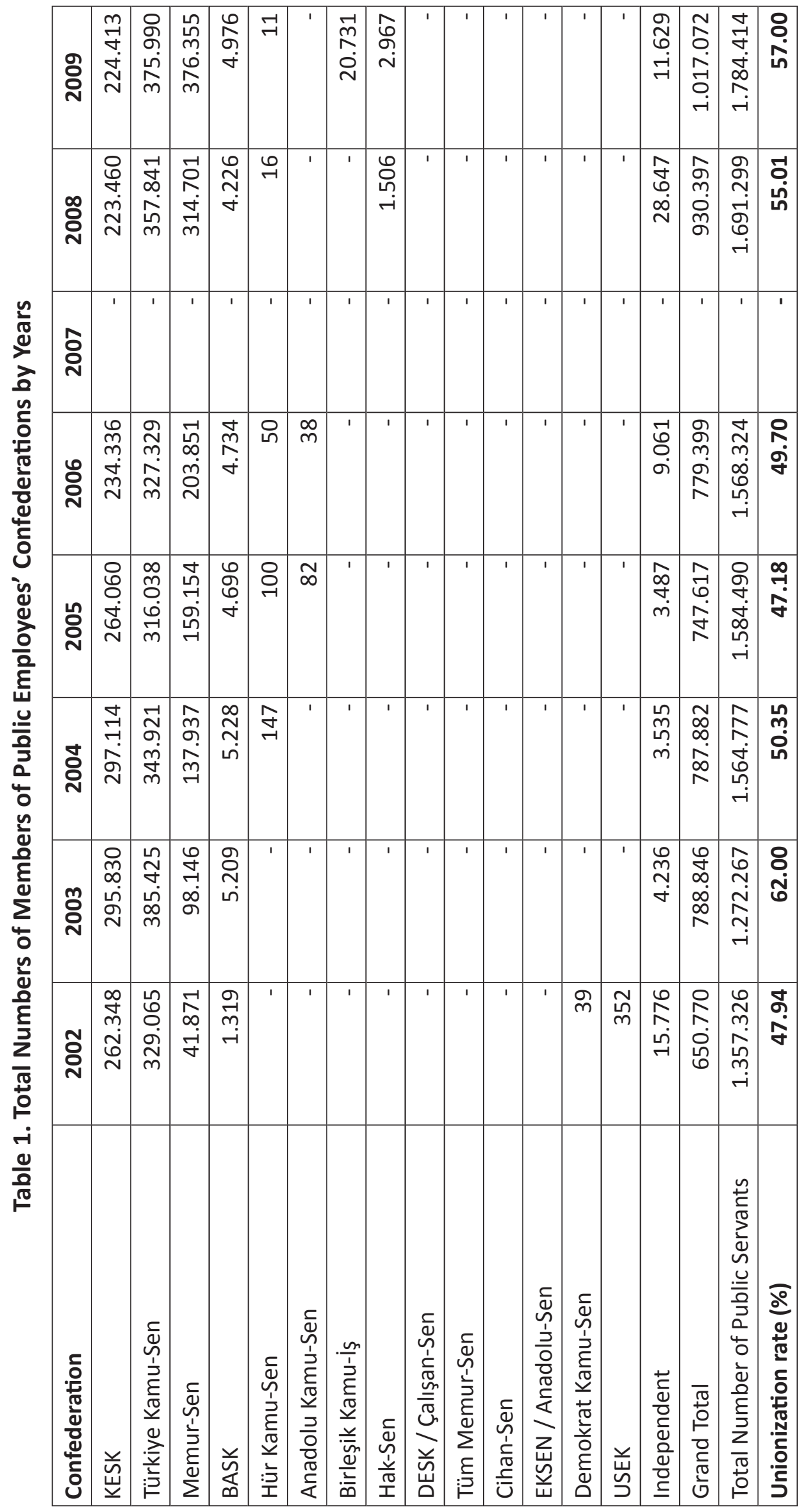




\begin{tabular}{|c|c|c|c|c|c|c|c|c|c|c|c|c|c|c|c|c|c|c|}
\hline$\stackrel{\infty}{\stackrel{N}{0}}$ & $\begin{array}{c}\hat{\infty} \\
\stackrel{1}{b} \\
\stackrel{f}{-}\end{array}$ & 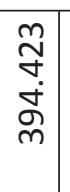 & 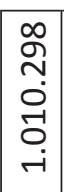 & \begin{tabular}{|c|}
$\stackrel{O}{\mathcal{C}}$ \\
$\stackrel{-}{+}$ \\
$\dot{+}$ \\
\end{tabular} & & & \begin{tabular}{l}
$\stackrel{\rho}{m}$ \\
\multirow{\sigma}{*}{}
\end{tabular} & $\begin{array}{l}0 \\
\infty \\
\infty \\
i \\
\end{array}$ & $\begin{array}{l}-1 \\
0 \\
\dot{\sigma}\end{array}$ & 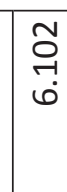 & & ஜู & 1 & & \begin{tabular}{|l|}
$\stackrel{\infty}{+}$ \\
$\stackrel{\sim}{-1}$ \\
$\stackrel{m}{m}$ \\
\end{tabular} & $\begin{array}{c}\infty \\
\tilde{n} \\
m \\
\tilde{n} \\
\hat{\sigma} \\
r\end{array}$ & 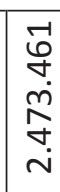 & ب̂ \\
\hline 공 & $\begin{array}{l}m \\
\stackrel{0}{+} \\
\hat{\sigma} \\
\stackrel{-1}{1}\end{array}$ & 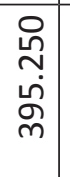 & 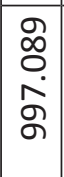 & 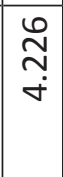 & ' & ' & $\begin{array}{l}\stackrel{\infty}{+} \\
\underset{\delta}{\sigma}\end{array}$ & $\begin{array}{l}\stackrel{n}{n} \\
\stackrel{n}{n}\end{array}$ & $\underset{\stackrel{\leftrightarrow}{\sim}}{\stackrel{\infty}{+}}$ & $\begin{array}{l}\vec{n} \\
\hat{n} \\
\emptyset\end{array}$ & 1 & 古 & ' & 1 & $\begin{array}{l}\stackrel{n}{m} \\
\stackrel{2}{0} \\
\text { Oे }\end{array}$ & 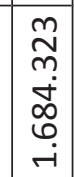 & $\begin{array}{l}\stackrel{\infty}{N} \\
\underset{\sim}{\sim} \\
\stackrel{\sim}{\sim}\end{array}$ & ஸे \\
\hline $\begin{array}{l}0 \\
\stackrel{2}{0} \\
\stackrel{N}{2}\end{array}$ & 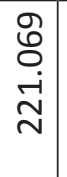 & 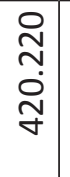 & $\mid \begin{array}{l}\tilde{n} \\
0 \\
\dot{\varphi} \\
\stackrel{n}{n}\end{array}$ & 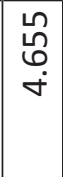 & ' & 1 & $\begin{array}{l}\text { \% } \\
\text { ஸ் }\end{array}$ & 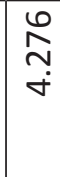 & \begin{tabular}{l} 
\\
\multirow{+}{+}{} \\
ம்
\end{tabular} & $\begin{array}{l}\stackrel{\sim}{n} \\
\infty \\
\\
\end{array}$ & 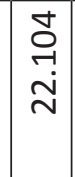 & $\stackrel{\vec{\infty}}{\wedge}$ & 1 & ' & \begin{tabular}{l}
$m$ \\
\multirow{f}{*}{} \\
$\stackrel{0}{\circ}$
\end{tabular} & 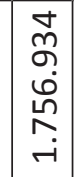 & 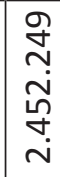 & 苮 \\
\hline 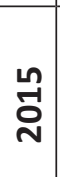 & 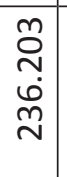 & 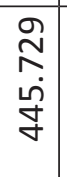 & $\begin{array}{l}n \\
0 \\
0 \\
6 \\
\infty \\
\infty \\
\infty\end{array}$ & \begin{tabular}{|l|}
$\stackrel{O}{0}$ \\
$\stackrel{m}{+}$ \\
$\dot{\sim}$
\end{tabular} & ' & 1 & $\begin{array}{l}\text { Un } \\
\text { m} \\
\text { ஸे }\end{array}$ & $\begin{array}{c}\underset{\infty}{+} \\
\stackrel{+}{+}\end{array}$ & $\begin{array}{l}\text { N } \\
\text { ô } \\
\text { மn }\end{array}$ & $\begin{array}{l}\infty \\
m \\
\infty \\
\infty\end{array}$ & $\begin{array}{l}\text { ঃ } \\
\text { О } \\
\text { ন }\end{array}$ & 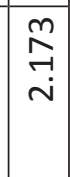 & 1 & 1 & $\begin{array}{l}\mathscr{0} \\
\stackrel{\infty}{二} \\
\stackrel{9}{+}\end{array}$ & 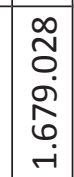 & 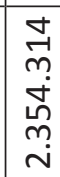 & $\stackrel{\sim}{n}$ \\
\hline 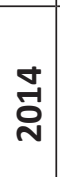 & 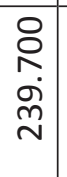 & $\begin{array}{l}\vec{f} \\
\dot{f} \\
\dot{f} \\
\dot{y}\end{array}$ & 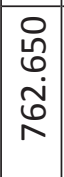 & \begin{tabular}{|l|}
$\infty$ \\
$\infty$ \\
$m$ \\
$m$ \\
\end{tabular} & & 1 & 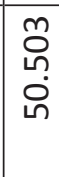 & $\begin{array}{l}\stackrel{\sim}{\infty} \\
\stackrel{+}{+}\end{array}$ & $\begin{array}{l}\text { g } \\
\stackrel{2}{2} \\
\text { ம }\end{array}$ & $\mid \begin{array}{l}-1 \\
0 \\
0 \\
\infty\end{array}$ & $\begin{array}{l}\text { 尺े } \\
\text { సं }\end{array}$ & 1 & 1 & ' & 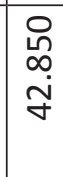 & $\begin{array}{l}\text { ठे } \\
\text { のุ } \\
\infty \\
\infty \\
\text { ஸ் }\end{array}$ & 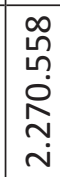 & o \\
\hline 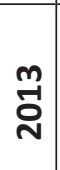 & $\begin{array}{c}\stackrel{0}{\infty} \\
\stackrel{-}{\sim} \\
\stackrel{n}{n}\end{array}$ & 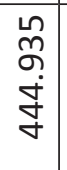 & $\begin{array}{l}\tilde{N} \\
0 \\
\hat{0} \\
\hat{0}\end{array}$ & $\begin{array}{l}0 \\
\tilde{o} \\
\dot{m} \\
\end{array}$ & & 1 & $\begin{array}{l}\vec{y} \\
\text { ठ } \\
\dot{8}\end{array}$ & $\begin{array}{l}\underset{\hat{O}}{+} \\
\dot{+}\end{array}$ & $\begin{array}{l}\text { Oे } \\
\text { + } \\
\dot{+}\end{array}$ & $\begin{array}{l}\text { f } \\
\infty\end{array}$ & 1 & 1 & ' & ' & 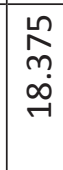 & 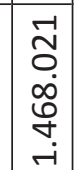 & $\begin{array}{l}\stackrel{\infty}{\tilde{n}} \\
\underline{\sigma} \\
\stackrel{\sim}{m} \\
\stackrel{\sim}{\sim}\end{array}$ & $\hat{\aleph}$ \\
\hline స్ & 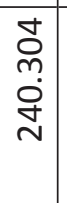 & $\begin{array}{l}\vec{\sigma} \\
\stackrel{2}{ } \\
\infty \\
\vec{\sigma}\end{array}$ & 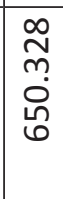 & $\begin{array}{l}\infty \\
0 \\
\dot{0} \\
\dot{m}\end{array}$ & 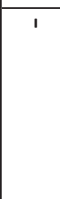 & 1 & $\begin{array}{l}\hat{\gamma} \\
\dot{\gamma} \\
m \\
m\end{array}$ & $\begin{array}{l}0 \\
-1 \\
0 \\
\dot{\sigma}\end{array}$ & 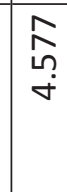 & 1 & ' & 1 & 1 & ' & $\begin{array}{l}\text { O } \\
\infty \\
\infty \\
\text { ○े }\end{array}$ & $\begin{array}{c}\vec{b} \\
6 \\
\dot{n} \\
n \\
r \\
r\end{array}$ & $\begin{array}{c}\infty \\
\text { o } \\
\text { م. } \\
\text { - } \\
\text { i }\end{array}$ & $\begin{array}{l}\text { f } \\
\text { fo } \\
0\end{array}$ \\
\hline$\underset{\sim}{-1}$ & 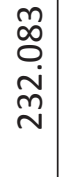 & 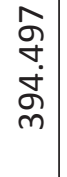 & \begin{tabular}{|l}
$\infty$ \\
$\stackrel{\infty}{n}$ \\
nn \\
மn
\end{tabular} & $\begin{array}{l}\hat{\sigma} \\
\dot{m} \\
\end{array}$ & 1 & ' & 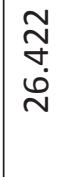 & 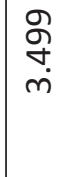 & 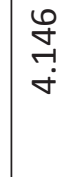 & 1 & ' & 1 & 1 & 1 & $\begin{array}{l}\text { 우 } \\
\text { ஸें } \\
\text { مी }\end{array}$ & 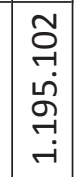 & 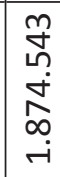 & กิ \\
\hline $\begin{array}{l}\text { Oे } \\
\text { Dे }\end{array}$ & 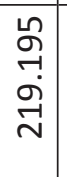 & 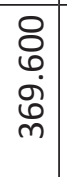 & $\begin{array}{l}\overrightarrow{-} \\
\stackrel{-}{\sim} \\
\stackrel{\text { I }}{m}\end{array}$ & 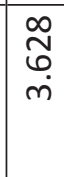 & $\infty$ & 1 & $\stackrel{\vec{n}}{\stackrel{\vec{n}}{\sim}}$ & \begin{tabular}{|l} 
\\
\\
0 \\
m
\end{tabular} & $\begin{array}{l}\vec{\infty} \\
\infty \\
i\end{array}$ & ' & I & ' & ' & I & $\begin{array}{l}\infty \\
\infty \\
0 \\
- \\
- \\
-\end{array}$ & 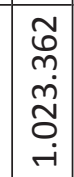 & $\begin{array}{l}\hat{n} \\
\hat{\sim} \\
\hat{\sigma} \\
\stackrel{-}{-}\end{array}$ & 官 \\
\hline 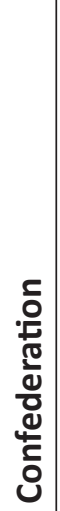 & $\begin{array}{l}\text { 饪 } \\
\end{array}$ & 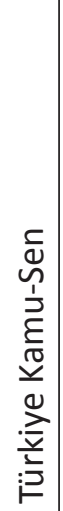 & 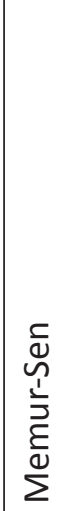 & 产 & 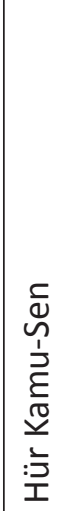 & 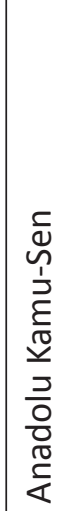 & 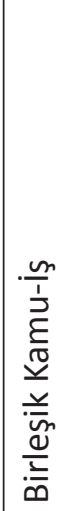 & 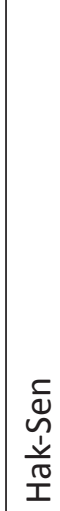 & 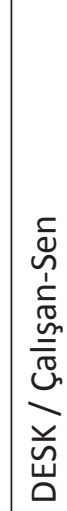 & 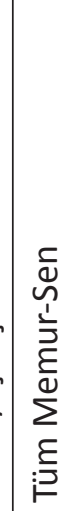 & 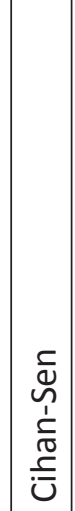 & 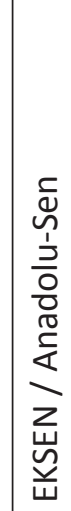 & 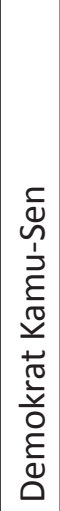 & \begin{tabular}{|l} 
\\
岕 \\
号
\end{tabular} & 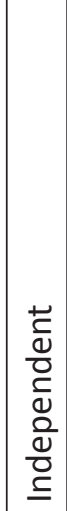 & $\begin{array}{l}\bar{\pi} \\
\tilde{0} \\
0 \\
0 \\
0 \\
\frac{0}{0} \\
\frac{0}{0}\end{array}$ & 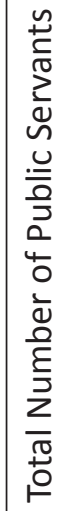 & 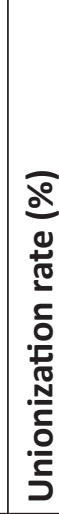 \\
\hline
\end{tabular}




\section{Conclusion}

It is seen that the unionization rate of public servants' unions, which obtained the right of payment for collective bargaining bonus in 2006, increased from approximately $49.70 \%$ in 2006 to nearly $68 \%$ in 2018 . It is considered that collective bargaining bonus payments could be effective in the rate of unionization by rendering promoting effect. The fact that the aforementioned bonus is paid only to unionized public servants appears to be problematic in terms of justice as a discriminatory practice. On the other hand, collective bargaining bonus payments, which provide indirect financing, constitute a separate problem area in terms of the fact that the unions independently fulfill the function of pressure group, fitting its purpose, in the advocacy of the economic and social rights of the public employees and the establishment of union consciousness. Finally, it is concluded that there is no significant theoretical basis for the collective bargaining bonuses included in public expenditure financed by public revenues.

\section{References}

Bailey, K.D. (1994). Methods of Social Reaserch, 4th ed., New York, The Free Press.

Berg, B.L., Howard, L., Hiperlink(Firm) \& Aydın, H (2015). Sosyal Bilimlerde Nitel Araştırma Yöntemleri, Konya, http://search.ebscohost.com/login.aspx? direct $=$ true \& db=nlebk\&AN=1683092 \&lang=tr\&site=eds-live \&scope=site \& authtype=ip,uid, (19.03.2019).

Ministry of Family, Labor and Social Services (2019a), Kamu Görevlileri Sendika Üye Sayıları Hakkında Tebliğler, https://www.ailevecalisma.gov.tr/tr-tr/istatistikler /calisma-hayati-istatistikleri/sendikal-istatistikler/kamu-gorevlileri-sendika-\%C3\%BCyesay\%C4\%B1lar\%C4\%B1-hakk\%C4\%B1nda-tebli\%C4\%9Fler/, (15.02.2019).

Ministry of Family, Labor and Social Services (2019b), İsçi Sayıları ve Sendikaların Üye Sayıları Hakkında Tebliğler, https://www.ailevecalisma.gov.tr/tr-tr/istatistikler/calisma-hayatiistatistikleri/sendikal-istatistikler/isci-sayilari-ve-sendikalarin-uye-sayilari-hakkindatebligler/, (25.03.2019).

Neuman, W.L. (2011). Social Research Methods: Qualitative and Quantitative Approaches, 7th ed., Boston, Pearson.

Özcan, Ş. (2005). Hükûmetler ve Bürokrasi Henüz Kamu Sendikacılığını Kabullenmiş veya İçine Sindirebilmiş Değildir, Sivil Toplum, Yıl: 3, Sayı: 12, ss.126-128. 